\title{
The Impact of Corporate Governance on the Cost of Equity: Empirical Evidence from Pakistani Listed Companies
}

\author{
Syed Zulfiqar Ali Shah" and Safdar Ali Butt ${ }^{* * *}$
}

\begin{abstract}
This study examines the impact of the quality of corporate governance, as measured by a specially constructed corporate governance index, on the expected cost of equity calculated using the capital asset pricing model (CAPM) approach. A total of 114 listed companies were investigated to analyze the relationship between the two variables for the period 2003 to 2007. The quality of corporate governance was measured by assigning weights to a set of related variables, although these variables were also considered individually. We used descriptive statistics, a correlation matrix, a simple ordinary least squares (OLS) approach, and fixed effect model to test the panel data collected. We found a negative relationship between managerial ownership and board size with the cost of equity, and a positive relationship between board independence, audit committee independence, and corporate governance with the cost of equity. These results could be due to the transition phase through which Pakistani companies are passing after the promulgation of the Code of Corporate Governance in 2002.
\end{abstract}

JEL Classification: G30, G34.

Keywords: Corporate governance, cost of equity, Pakistan.

\section{Introduction}

While public attention was drawn to the importance of corporate governance only after major scandals such as Enron and WorldCom were unearthed, it would be wrong to assume that the concept of corporate governance is new. The need for good corporate governance arose at about the same time that the ownership and management of corporate entities were separated, and the application of agency theories set in. Like the proverbial child who must cry for his mother's attention, companies have always needed good corporate governance but only when small investors

* ** Mohammad Ali Jinnah University, Islamabad. 
started to cry out (after losing heavily in corporate scandals) did regulators and professional bodies start paying formal attention to developing and documenting more elaborate mechanisms of corporate governance.

The prime objective of corporate governance is to ensure protection of the interests of all stakeholders of a company. Responsible decisionmaking at the board level communicated transparently on a timely basis to all those concerned gives equity providers greater confidence in a company. In turn, this reduces the perception of risk and ultimately curtails the cost of equity.

In developed markets, this has been proven by a number of studies conducted by regulators, governments, and independent institutions. The theme of current worldwide corporate governance has been influenced by reports issued by the Cadbury Committee (1992), Greenbury Committee (1995), Hampel Committee (1998), and Turnbull Committee (2003), and Higgs (2003). Several corporate governance codes and recommendations have emerged on the basis of these reports and are practiced in different parts of the world.

Corporate governance is even more important for emerging and less developed markets-Pakistan is no exception. The first Code of Corporate Governance in Pakistan was promulgated in March 2002 by the Securities and Exchange Commission of Pakistan (SECP), the apex regulator of the country's corporate sector.

The relationship between corporate governance and the cost of equity has been extensively examined in developed and emerging markets. However, no comprehensive or significant work has been done in this regard in Pakistan. This study is an effort to bridge the gap, providing an insight into the relationship between different but pertinent variables as well as facilitating financial managers and policymakers in making judicious and rational financial decisions.

With reference to Pakistan, the study is important because the Pakistani corporate sector has traditionally been dominated by family-owned businesses and nonprofessional boards of directors elected on the basis of their links with concentrated ownership. In this situation, decisions are perceived to serve the interest of only one party, making it difficult to gain and sustain the trust of other stakeholders. With the company permanently controlled by one family with limited access to funds and a restricted professional base, the decision-making process at the board level is apt to stagnate. Generally, investing does not support family-controlled companies 
as the family is (often rightly) deemed to make all decisions to suit its own interests. Many such families often expropriate the dues of other stakeholders. This means that, for a family-controlled company to become a truly public company, a very high level of agency costs are involved, pushing up the company's weighted average cost of capital (WACC). In turn, a higher WACC deters the investing public. Thus, many family-controlled companies find themselves in a Catch 22 situation: low availability of funds due to higher agency costs, and higher agency costs due to low availability of funds.

A high WACC has other damaging consequences. Since it is normally used as the opportunity cost for evaluating any further investment opportunities, very few new investments can measure up to the high level of return sought. This curtails both growth and diversification possibilities. The cost of equity is one of the foremost constituents of WACC-in unleveraged companies, it is the only component of WACC. The high cost of equity is a severe deterrent for managers and a serious impediment to attempts to raise additional funds.

The other side of the coin is that if companies succeed in gaining and sustaining the confidence of the investing public, their cost of equity will shrink. This brings down the threshold of internal rate of return (IRR) sought from new projects-opening doors for expansion and diversification-with positive consequences for the company, its stakeholders, and the country.

The purpose of this study is to highlight the relationship between corporate governance practices (which help a company gain and sustain the confidence of the investing public) and the cost of equity (which helps a company grow and diversify). Our findings may provide direction to policymakers to augment or modify the extent and depth of corporate governance practices, helping the growth of a proper corporate culture in the country.

The study is organized as follows. The next section lists the work already carried out by other researchers in the form of a literature review. The third section elucidates the study's data and methodology. The fourth section presents and discusses the study's results. The fifth section presents conclusions drawn from the study.

\section{Literature Review}

This section is organized into three parts: the first summarizes the literature on corporate governance, the second section lists studies relevant to 
the cost of equity capital, and the third section includes literature that studies the relationship between corporate governance and the cost of equity capital.

\subsection{Corporate Governance}

Managers are considered responsible for making decisions to protect the interests of society as well as the interests of their organization. This behavior is necessary for companies themselves, although some scholars argue that considerations of social responsibility should not enter the decision-making process. However, many institutional investors pay attention to corporate social behavior and thus influence the market for a company's stock.

Corporate governance has been increasingly emphasized both in practice and academic research (e.g., Blue Ribbon Committee Report 1999, Ramsay Report 2001, Sarbanes-Oxley 2002, Bebchuk and Cohen 2009). This emphasis is due in part to the prevalence of highly publicized and egregious financial reporting frauds such as Enron, WorldCom, Aldelphia, and Parmalat; an unprecedented number of earnings restatements (Wu, et al 2002; Palmrose and Scholz 2002; Larcker, et al 2004); and claims of blatant earnings manipulation by corporate management (Krugman 2002). Further, academic research has found an association between weaknesses in governance and poor financial reporting quality, earnings manipulation, financial statement fraud, and weaker internal controls (Dechow, et al 1996; Beasley 1996). Given these developments, there has been an emphasis on the need to improve corporate governance over the financial reporting process (Levitt 1998, 1999, 2000), such as enacting reforms to improve the effectiveness of the audit committee (Blue Ribbon Committee 1999; Sarbanes-Oxley Act 2002) and to make the board of directors and management more accountable for ensuring the integrity of financial reports (SEC 2002, The Business Roundtable 2002) as well as a rapidly expanding body of research on corporate governance.

Corporate governance practices can be determined by the scope and nature of associated agency problems (agency characteristics) of firms, i.e., their need to attract external investment or external investors' difficulties in monitoring the firms. As La Porta, et al (1998) argue, good corporate governance is needed for better access to external financing at a lower cost. This indicates that firms in need of a good deal of external financing, such as rapidly growing firms, have an incentive to improve their corporate governance. In addition, as Himmelberg, Hubbard, and Palia (1999) argue, firms facing large information asymmetries because of other characteristics of their firms may signal to the market their intent to better protect 
investors by adopting good corporate governance policies. This might be the case for large firms, young firms, or firms with relatively large intangible assets.

\subsection{Measuring Corporate Governance Practices}

In the literature, different authors have used different criteria to measure the efficacy of corporate governance practices. Some have used score boards, others have directly identified variables for corporate governance and independently investigated relationships they wanted to capture. Some have used both methods in their research. The corporate governance rankings by the investment bank Brunswick Warburg that Black (2000) uses are based on eight corporate governance elements with different weights: (i) disclosure and transparency, (ii) dilution through share issuance, (iii) asset stripping and transfer pricing, (iv) dilution through a merger or restructuring, (v) bankruptcy, (vi) limits on foreign ownership, (vii) management's attitude toward shareholders, and (viii) registrar risk.

Black, Jang, and Kim (2003) choose 42 items from 123 survey questions, excluding those asking management's views rather than facts, those irrelevant to corporate governance, those that are ambiguous as to whether they represent good or bad corporate governance, and those to which the answers vary little from firm to firm. They then classify the 42 items into four categories, each of which has an equal weight of 0.25 : (i) shareholders' rights, (ii) the board of directors in general, (iii) outside directors, and (iv) disclosure and transparency.

The survey that Klapper and Love (2002) use comprises a total of 57 questions with "yes" or "no" answers. They are classified into the following seven categories: (i) discipline, (ii) transparency, (iii) independence, (iv) accountability, (v) responsibility, (vi) fairness, and (vii) social awareness. Each category has a weight of 0.15 except for the last one, which has a weight of 0.10 .

Chhaochharia, et al (2005) measure corporate governance using four different variables: (i) insiders' engagement in fraudulent activity, (ii) the existence of well-functioning internal control mechanisms, (iii) insiders' engagement in related party transactions, and (iv) the compliance of the board of directors with the new independence requirements.

Chen (2004) includes 57 criteria that are grouped into seven major categories: (i) transparency, (ii) management discipline, (iii) independence, (iv) accountability, (v) responsibility, (vi) fairness, and (vii) social awareness. 
Opinion surveys of professional investors could provide some guidance on the construction of corporate governance scores. McKinsey \& Company's (2002) survey respondents say that, for corporations, timely and broad disclosure is the highest priority, followed by independent boards, effective board practices, and performance-related compensation for directors and management.

Investors' responses will, of course, reflect their major concerns given the realities in particular regions or countries. A survey by PricewaterhouseCoopers Indonesia and the Jakarta Stock Exchange (2002) reports that what Indonesian institutional investors value most highly includes the disclosure of related-party transactions and corporate governance practices. The existence of corporate governance codes and business ethics as well as the quality and independence of external auditors, audit committees, and commissioners and directors is also important. The existence of nomination and remuneration committees and the number of independent commissioners seem to be less essential for their investment decisions.

However, as Klapper and Love (2002) found, the effect of corporate governance on firm performance may vary depending on the country-specific level of investor protection. More specifically, firms with relatively good governance practices are likely to be more highly valued by investors in countries where investor protection is generally poor. Extending this argument, we can also expect the market to assess the same corporate governance differently depending on corporations' ownership and control structure. For instance, if the market suspects that controlling owners can find ways to maximize their interests at the expense of other shareholders however good their firms' corporate governance practices may appear then the market is likely to discount the value of measured corporate governance.

\subsection{Cost of Capital}

The cost of equity capital has been interpreted differently by different researchers in the literature. Some have used the ex-ante cost of equity while others are inclined to use the ex-post cost of equity. Most of the recent literature focuses on the use of the ex-ante approach to measuring the cost of equity. Various models have been employed to calculate the cost of equity. Ohlson and Nauroth (2005) use an EPS and EPS growth model. They have developed a model relating firm price per share with next year's expected earnings per share, and short-term growth in earnings per share with long-term growth in earnings per share. This model can be contrasted with the standard Gordan-Williams model (see Appendix C): 


$$
K=A+\sqrt{A^{2}+\frac{e_{1}}{P_{0}}\left[g_{2}-(y-1)\right]}
$$

Another model used by Claus and Thomas (2001) is based on the residual income valuation approach. This is similar to the dividend discount mode1; the difference is that it uses future earnings per share with shortterm and long-term growth rates. The model is represented by the following equation (see Appendix C):

$P_{T}=B_{T}+\frac{E P S_{T+1}-K B_{T}}{(1+K)}+\frac{E P S_{T+2}-K B_{T+1}}{(1+K)^{2}}+\ldots \ldots+\frac{E P S_{T+5}-K B_{T+4}}{(1+K)^{5}}+\frac{\left(E P S_{T+5}-K B_{T+4}\right)(1+g n)}{(K-g n)(1+K)^{5}}$

Gebhardt, Lee, and Swaminathan (2001, referred to as GLS) use a model similar to the one used by Claus and Thomas, i.e., also based on the residual income valuation approach, the only difference being that, in the latter, growth was taken up to 5 years, while in the former, it was extended to 12 years.

Easton (2004, referred to as ES) base their calculations on an abnormal growth model, in which they use actual earnings forecasts for 2 years, dividend payout ratio, and current price, and manually search for the cost of equity capital $(\mathrm{K})$ that leads to balancing the two sides of the equation. The equation is given below (see Appendix C):

$$
P_{T}=\frac{E P S_{T+2}+K D_{T+1}-E P S_{T+1}}{\mathrm{M}^{2}}
$$

The above mentioned models are relatively new, but the foundations for the development of calculating cost of equity capital models were laid by Markowitz (1952) and Tobin (1958). Since then, various new models have emerged. The CAPM (capital assets pricing model), which has been used in this study, was developed by Sharpe (1964) and Lintner (1965), and relates the cost of equity capital of an individual security to a measure of its systematic risk (Beta).

Studies on the CAPM such as Lintner (1965) and Douglas (1969) were initially based on individual security returns. However, some statistical problems arose while calculating individual security-based returns which were identified by Miller and Scholes (1972) in testing the validity of the CAPM. Subsequent studies overcame this problem by using portfolio returns. Black, Jensen and Scholes (1972) use all the stocks of the NYSE spread over a time horizon, form portfolios, and report a linear relationship between the average excess portfolio return and the beta. Fama and 
MacBeth (1973) extended the study and provided evidence (i) of a larger intercept term than the risk-free rate, (ii) that the linear relationship between the average return and the beta holds, and (iii) that the linear relationship holds well when the data are spread over a long time period.

\subsection{Corporate Governance and Cost of Equity}

Chen, et al (2007) investigated the effects of disclosure and other corporate governance mechanisms on equity liquidity and found that those companies with poor information transparency and disclosure practices face a greater economic cost of equity liquidity. With the same view, Ashbaugh, et al (2004) conjectured that, since governance attributes are intended to reduce agency costs, they should have a significant effect on firms' cost of equity capital; they found that the quality of firms' financial information is negatively related to firms' cost of equity.

Chen, et al (2004) examined the effects of firm-level disclosure and corporate governance on the cost of equity capital. They found that disclosure can significantly lower the cost of equity in emerging markets, and that this effect is observed only in countries that protect investors relatively well. Thus, firm-level disclosure and country-level legal protection seem to play a complementary role in reducing a firm's cost of equity. They further found that corporate governance always has a significantly negative effect on the cost of equity capital under various regression specifications. In addition, this effect is significant only in countries that provide relatively poor legal protection for investors.

Contrary to the above studies Guedhami and Mishra (2006) found robust evidence that the implied cost of equity increases with excess control. Another aspect of corporate governance was highlighted by Hope (2007) in his study on the impact of excessive auditor remuneration on the cost of equity, which found that the cost of equity increases if auditors' remuneration is excessive but only in countries with stronger investor protection.

Clearly, corporate governance has a great deal of influence on the cost of capital. We are interested in investigating the importance of corporate governance on the cost of equity in Pakistan, where regulatory authorities are attempting to promote good corporate governance among business sector entities. 


\section{Data and Methodology}

\subsection{Sample}

The sample comprised 114 listed companies selected from the Karachi Stock Exchange (KSE)-listed companies spanning different sectors for the period 2003-2007. It excludes financial companies (because their capital structure and profits are different from other companies), and companies for which no data were available.

Sources of data included annual reports, the State Bank of Pakistan's balance sheet review, companies' web sites, and in certain cases direct contact with company officials.

The following table lists the total number of listed companies in each sector and the number chosen for our study:

Table-1

\begin{tabular}{llcc}
\hline No. & Name of Sector & No. of Companies & Used in Study \\
\hline 1. & Sugar & 40 & 16 \\
2. & Cement & 24 & 7 \\
3. & Oil and Gas Marketing & 7 & 1 \\
4. & Textile Spinning & 109 & 57 \\
5. & Automobile Assembler & 13 & 2 \\
6. & Jute & 6 & 1 \\
7. & Oil and Gas Exploration & 4 & 3 \\
& Power Generation and & & \\
8. & Distribution & 13 & 1 \\
9. & Refinery & 4 & 3 \\
10. & Tobacco & 3 & 2 \\
11. & Fertilizers & 5 & 4 \\
12. & Pharmaceuticals & 8 & 7 \\
13. & Chemicals & 25 & 7 \\
14. & Food and Personal Care & & 1 \\
15. & Products & 23 & 2 \\
\hline
\end{tabular}




\subsection{Methodology}

The study's hypothesis is as follows:

$\mathrm{H}_{0}=$ corporate governance does not impact the cost of capital

$\mathrm{H}_{1}=$ corporate governance impacts the cost of capital been used.

In order to test the hypothesis, the following methodologies have

Since our objective is to measure the extent of the impact of corporate governance on a company's cost of equity, the latter is a dependent variable while the various aspects of corporate governance (practices) have been used as independent variables. As seen in the literature review, there are a number of factors that influence the cost of equity; we have used two control variables, namely return on equity (ROE) and size ( $\log$ of total assets). Corporate governance is a qualitative variable, incapable of being measured directly. We have therefore used proxies for this purpose, each of which has its own limitations. The empirical literature provides a number of proxies used to quantify corporate governance. These range from the individual factor to the score card approach; the latter entails the combined effect of all factors of corporate governance. We have attempted to capture the effect of individual factors as well as the collective effect of the concerned variables.

\subsection{Model Used to Measure Corporate Governance}

In this paper, in line with Klapper and Love (2002), the quality of corporate governance (QCG) has been estimated by the use of following equation.

$$
\mathrm{QCG}=\mathrm{f}(\mathrm{BS}, \mathrm{OS}, \mathrm{AI})
$$

Where $\mathrm{BS}=$ board structure, OS = ownership structure, and AI = audit committee independence.

The theoretical framework of corporate governance measurement has been shown in the above equation. These variables have been used, once independently to use them as a proxy for corporate governance, and collectively in the calculation of the corporate governance score for each company. The method applied to estimate the corporate governance score (CGS) has been given in Appendix B. 


\subsection{Cost of Equity}

The cost of equity capital has been calculated using CAPM in line with Fama and French. The equation used in the calculation is as follows:

$$
\mathrm{Ke}=\mathrm{R}_{\mathrm{fr}}+\beta\left(\mathrm{R}_{\mathrm{m}}-\mathrm{R}_{\mathrm{fr}}\right)
$$

Where $\mathrm{Ke}=$ cost of equity, $\mathrm{R}_{\mathrm{fr}}=$ risk free rate, $\mathrm{R}_{\mathrm{m}}=$ market rate and $\beta=$ beta.

Beta $(\beta)$ has been calculated on the basis of 2 years' monthly returns using the following formula.

$$
\beta=\operatorname{Cov}{ }_{(\text {Security \& Market) }} / \operatorname{Var}_{\text {(Market) }}
$$

Return on equity (ROE) (net profit after tax/shareholders' equity) is a measure of the returns being earned by the company on shareholders' equity. It has been used as control variable in finding out the relationship because of its impact on the risk of the company. The higher the return on equity, the more comfortable the investors, and the lower the risk.

The log of total assets has been used as a proxy for firm size. Larger companies will have lower risks and investors will be more willing to accept lower returns from such companies.

\section{Data Analysis and Results}

Table-2: Descriptive Statistics (Corporate Governance Measured by Individual Factors)

\begin{tabular}{lcccccccc}
\hline & Ke & F/SIZE & OC & MO & BI & ACI & BS & ROE \\
\hline Mean & 0.29 & 18.57 & 0.99 & 0.37 & 1.08 & 1.24 & 1.83 & 0.36 \\
Median & 0.19 & 20.48 & 0.86 & 0.21 & 0.57 & 0.67 & 1.95 & 0.12 \\
Maximum & -0.93 & 3.59 & 0.00 & 0.00 & 0.00 & 0.00 & -9.21 & -26.88 \\
Minimum & 1.91 & 25.15 & 80.43 & 27.33 & 14.00 & 66.67 & 2.89 & 39.30 \\
Std. Dev. & 0.36 & 5.20 & 3.44 & 1.64 & 2.21 & 6.22 & 0.89 & 2.49 \\
\hline
\end{tabular}

$\mathrm{K}_{\mathrm{e}}=$ cost of equity, $\mathrm{F}$ size $=\log$ of total assets, $\mathrm{OC}=$ ownership concentration, $\mathrm{MO}=$ managerial ownership, $\mathrm{BI}=$ board independence, $\mathrm{ACI}=$ audit committee independence, $\mathrm{BS}$

$=$ board size, $\mathrm{ROE}=$ return on equity. 
Descriptive statistics have been used to check the nature and range of the data, followed by the application of correlation analysis:

Table-3: Correlation Matrix (Corporate Governance Measured by Individual Factors)

\begin{tabular}{|c|c|c|c|c|c|c|c|c|}
\hline & $\mathrm{Ke}$ & $\begin{array}{l}\text { Log } T \\
\text { Assets }\end{array}$ & OC & MO & BI & ACI & BS & ROE \\
\hline $\mathrm{Ke}$ & 1 & & & & & & & \\
\hline $\begin{array}{l}\text { Log } \mathrm{T} \text {. } \\
\text { Assets }\end{array}$ & $-0.1182^{* * *}$ & 1 & & & & & & \\
\hline$P$ values & $\underline{0.005913}$ & & & & & & & \\
\hline OC & 0.0157 & 0.0263 & 1 & & & & & \\
\hline$P$ values & $\underline{0.715596}$ & $\underline{0.541588}$ & & & & & & \\
\hline MO & -0.0227 & 0.0005 & $0.8055^{* * *}$ & 1 & & & & \\
\hline$P$ values & $\underline{0.598308}$ & $\underline{0.990743}$ & $\underline{0}$ & & & & & \\
\hline B.I. & 0.0755 & $0.2432^{* * * *}$ & -0.0212 & -0.0537 & 1 & & & \\
\hline$P$ values & $\underline{0.07934}$ & $\underline{0}$ & $\underline{0.622709}$ & $\underline{0.218412}$ & & & & \\
\hline Audit & -0.0026 & 0.0413 & -0.0043 & -0.0232 & -0.0311 & 1 & & \\
\hline$P$ values & $\underline{0.962982}$ & $\underline{0.337659}$ & $\underline{0.920515}$ & $\underline{0.59348}$ & $\underline{0.471804}$ & & & \\
\hline $\begin{array}{l}\text { Board } \\
\text { size }\end{array}$ & -0.063 & $-0.1903^{* * *}$ & 0.0158 & 0.035 & $-0.6893 * * *$ & 0.0173 & 1 & \\
\hline$P$ values & $\underline{0.143356}$ & $\underline{0.000009}$ & $\underline{0.713864}$ & $\underline{0.416536}$ & $\underline{0}$ & $\underline{0.688062}$ & & \\
\hline ROE & -0.0783 & $0.1351^{* * *}$ & 0.0015 & 0.0014 & 0.0248 & 0.0117 & -0.0074 & 1 \\
\hline$P$ values & $\underline{0.06879}$ & $\underline{0.001635}$ & $\underline{0.972232}$ & $\underline{0.974083}$ & $\underline{0.564894}$ & $\underline{0.785995}$ & $\underline{0.863655}$ & \\
\hline
\end{tabular}

Values marked with *** are significant at 0.01 significance level.

From the above correlation matrix it is clear that only BI and OC are positively correlated with $\mathrm{Ke}$ while all other variables including control variables are negatively correlated. $P$ values are underlined to indicate the significance of the relationship.

A 5 -year panel data of 15 different industries has been empirically analyzed. Two models have been used for the analysis and been compared as well. In the first instance, assuming that the basic assumptions of the classical linear regression model hold true, data have been analyzed using the OLS method according to the following equation. The results are shown in Table-4.

$$
Y_{i t}=\alpha_{1}+\sum \beta_{1} X_{i t}+\mu_{t}
$$


Where $\sum X_{i t}$ is a set of independent variables and $\mu_{t}$ is the error term in year $t$.

The above equation can also be written as:

$\mathrm{Ke}_{\mathrm{it}}=\propto_{1}+\beta 1$. Fsize $+\beta 2 . \mathrm{OC}_{\mathrm{it}}+\beta 3 . \mathrm{MO}_{\mathrm{it}}+\beta 4 . \mathrm{BI}_{\mathrm{it}}+\beta 5 . \mathrm{ACI}_{\mathrm{it}}+\beta 6 . \mathrm{BS}_{\mathrm{it}}+$ $\beta 7 . \mathrm{ROE}_{\mathrm{it}}+\mu_{\mathrm{it}}$

Where $\mathrm{Ke}=$ cost of equity, $\mathrm{F}$ size $=\log$ of total assets, $\mathrm{OC}=$ ownership concentration, $\mathrm{MO}=$ managerial ownership, $\mathrm{BI}=$ board independence, $\mathrm{ACI}=$ audit committee independence, $\mathrm{BS}=$ board size, $\mathrm{ROE}$ $=$ return on equity.

Table-4: OLS Method (Corporate Governance Measured by Individual Factors)

\begin{tabular}{lcc}
\hline & Coefficient & T values \\
\hline Intercept & 0.469314106 & 6.275847641 \\
Log T. Assets & -0.009447219 & -3.238116858 \\
OC & 0.010429318 & 1.426068793 \\
MO & -0.021240946 & -1.381901397 \\
BI & 0.014588404 & 1.546201726 \\
Audit & 0.000306093 & 0.127622373 \\
Board size & -0.010826306 & -0.469008157 \\
ROE & $-1.59761 \mathrm{E}-06$ & -1.478101538 \\
R Square & 0.033687901 & \\
Adjusted R Square & 0.021651985 & \\
\hline
\end{tabular}

\begin{tabular}{cc}
\hline \multicolumn{2}{c}{ Significance } \\
\hline $\mathrm{F}$ & $\mathrm{F}$ \\
2.798947873 & 0.007174906 \\
\hline
\end{tabular}

The value of $\mathrm{R}$ squared indicates that only $3.3 \%$ of variability is explained by the independent variables, which could be due to the nonconsideration of other variables which also impact the cost of equity. The adjusted $\mathrm{R}$ squared is not satisfactory, but as far as the $\mathrm{F}$ statistic is 
concerned, it shows that model used is valid. From the above table, we observe that:

$\mathrm{OC}$ and $\mathrm{BI}$ are positively correlated with the cost of equity and have a slightly significant relationship,

- MO has a negative but slightly significant impact on the cost of equity,

- Among the control variables ROE does not have any significant impact on $\mathrm{Ke}$,

- Firm size has a strong negative significant impact on the cost of equity.

The above analysis appears to yield certain confusing or conflicting results. One probable cause is the validity (or otherwise) of the assumptions used for the OLS method. For example, the slope coefficient may be constant but with a varying intercept across individual industries. On the other hand, the intercept may vary individually as well as over time or may be constant among individuals and vary across time. The fixed effect model has been applied to capture these possibilities:

$$
Y_{i t}=\alpha_{1 i}+\sum \beta_{1} X_{i t}+\mu_{i t}
$$

The subscript ${ }_{\mathrm{i}}$ on the intercept means that the intercepts of the 15 industries may be different. This difference may be due to the special features of industries over time.

The above equation can also be written as

$$
\begin{aligned}
& \mathrm{Ke}_{\mathrm{it}}=\propto_{1}+\alpha_{2} \cdot \mathrm{D}_{1 \mathrm{i}}+\alpha_{3} \cdot \mathrm{D}_{3 \mathrm{it}}+\ldots+\alpha_{14} \cdot \mathrm{D}_{14 \mathrm{i}}+\beta_{1} \cdot \mathrm{OC}_{\mathrm{it}}+\beta_{2} \cdot \mathrm{MO}_{\mathrm{it}}+\beta_{3} \cdot \mathrm{BI}_{\mathrm{it}}+\beta_{4} \cdot \mathrm{BS}_{\mathrm{it}} \\
& +\beta_{5} \cdot \mathrm{ACI}_{\mathrm{it}}+\beta_{5} \cdot \mathrm{F} \mathrm{Size}_{\mathrm{it}}+\beta_{5} \cdot \mathrm{ROE}_{\mathrm{it}}+\mu_{\mathrm{it}}
\end{aligned}
$$

Where $\mathrm{D}_{1 \mathrm{i}}---\mathrm{D}_{14 \mathrm{i}}$ are dummy variables which have been used to capture interindustry intercept differences. Applying the test yields the following results: 
Table-5: Fixed Effect Model (assuming intercept varies across individuals but constant over time)

Dependent Variable: Ke

Method: Least Squares

Included observations: 541 after adjustments

\begin{tabular}{lcccc}
\hline Variable & Coefficient & Std. Error & t-Statistic & Prob. \\
\hline OC & 0.008672 & 0.007148 & 1.213163 & 0.2256 \\
MO & -0.015291 & 0.015117 & -1.011487 & 0.3123 \\
BI & 0.000375 & 0.014972 & 0.025030 & 0.9800 \\
BS & -0.018172 & 0.010585 & -1.716727 & 0.0866 \\
ACI & 0.000496 & 0.002349 & 0.211330 & 0.8327 \\
F Size & -0.008912 & 0.003453 & -2.581341 & 0.0101 \\
ROE & -0.003841 & 0.005905 & -0.650532 & 0.5156 \\
D1 & -0.015151 & 0.045571 & -0.332477 & 0.7397 \\
D2 & -0.122913 & 0.114587 & -1.072659 & 0.2839 \\
D3 & 0.118906 & 0.085622 & 1.388741 & 0.1655 \\
D4 & -0.169461 & 0.065647 & -2.581421 & 0.0101 \\
D5 & -0.069298 & 0.154917 & -0.447324 & 0.6548 \\
D6 & 0.016632 & 0.118951 & 0.139821 & 0.8889 \\
D7 & 0.290684 & 0.106252 & 2.735802 & 0.0064 \\
D8 & 0.303791 & 0.097343 & 3.120832 & 0.0019 \\
D9 & 0.143424 & 0.156435 & 0.916827 & 0.3597 \\
D10 & 0.293061 & 0.111274 & 2.633685 & 0.0087 \\
D11 & 0.284533 & 0.176831 & 1.609068 & 0.1082 \\
D12 & 0.157923 & 0.064544 & 2.446751 & 0.0147 \\
D13 & -0.014048 & 0.113779 & -0.123471 & 0.9018 \\
D14 & 0.148420 & 0.243748 & 0.608909 & 0.5429 \\
C & 0.563607 & 0.105402 & 5.347194 & 0.0000 \\
R-squared & 0.101047 & Mean dependent var & 0.289258 \\
Adjusted R-squared & 0.064673 & S.D. dependent var & 0.353618 \\
S.E. of regression & 0.341992 & Akaike info criterion & 0.731756 \\
Sum squared resid & 60.70146 & Schwarz criterion & 0.906350 \\
Log likelihood & -175.9401 & F-statistic & & 2.778009 \\
Durbin-Watson stat & 1.725534 & Prob(F-statistic) & 0.000046 \\
\hline
\end{tabular}


By incorporating the representation of each industry, both the variation constant and adjusted $R$ squared terms have been improved. This shows that, by adding other variables, variation can be removed. In this test:

- $\mathrm{OC}$ and BI still show a positive impact on cost of equity which is statistically insignificant.

- BS has a negative effect on cost of equity which is slightly significant.

- MO has a negative impact on cost of equity which is also insignificant.

- Audit committee independence has an insignificant positive impact on $\mathrm{Ke}$.

- ROE has a negative impact on Ke but it is insignificant.

- Firm size still has a strongly negative significant impact on cost of equity.

The study covered 15 different industrial sectors. To avoid the dummy trap, we used 14 dummy variables, of which the majority of coefficients were found to be significant with very low $p$ values. We also found that most industries in our analysis did not have similar coefficients.

In our second analysis using the fixed effects model, we assumed that the intercept varies across individuals as well as over time. The time factor was also included in the study as an acknowledgement of the fact that different economic policies and changes in the status of economic factors alter the relationship of CG and Ke.

The results of the model are shown in Table-6 and the equation given below.

$\mathrm{Ke}_{\mathrm{it}}=\propto_{1}+\alpha 1 \cdot \mathrm{D}_{1 \mathrm{i}}+\alpha_{3} \cdot \mathrm{D}_{3 \mathrm{it}}+\ldots+\alpha_{14} \cdot \mathrm{D}_{14 \mathrm{i}}+\Upsilon_{0}+\Upsilon_{1} \cdot \mathrm{D} 15+\Upsilon_{2} \cdot \mathrm{D}_{16}+\Upsilon_{3} \cdot \mathrm{D}_{17}+$ $\Upsilon_{4} \cdot \mathrm{D}_{18}+\beta_{1} \cdot \mathrm{OC}_{\mathrm{it}}+\beta_{2} \cdot \mathrm{MO}_{\mathrm{it}}+\beta_{3} \cdot \mathrm{BI}_{\mathrm{it}}+\beta_{4} \cdot \mathrm{BS}_{\mathrm{it}}+\beta_{5} \cdot \mathrm{ACI}_{\mathrm{it}}+\beta_{5} \cdot \mathrm{F} \mathrm{Size}_{\mathrm{it}}+\beta_{5} \cdot \mathrm{ROE}_{\mathrm{it}}+$ $\mu_{\mathrm{it}}$

Where $+\Upsilon_{0}+\Upsilon_{1} \cdot D_{04}+\Upsilon_{2} \cdot D_{05}+\Upsilon 3 . D_{06}$ are time dummies used to capture the differences in intercepts due to time. 
Table-6: Fixed Effects Model (assuming intercept varies across individuals as well as over time)

\begin{tabular}{|c|c|c|c|c|}
\hline \multicolumn{5}{|c|}{$\begin{array}{l}\text { Dependent Variable: Ke } \\
\text { Method: Least Squares } \\
\text { Date: 07/09/08 Time: } 15: 15 \\
\text { Sample (adjusted): } 1560 \\
\text { Included observations: } 541 \text { after adjustments }\end{array}$} \\
\hline Variable & Coefficient & Std. Error & t-Statistic & Prob. \\
\hline$\overline{\mathrm{OC}}$ & 0.009031 & 0.006839 & 1.320418 & 0.1873 \\
\hline $\mathrm{MO}$ & -0.019821 & 0.014454 & -1.371352 & 0.1709 \\
\hline $\mathrm{BI}$ & 0.001087 & 0.014255 & 0.076250 & 0.9392 \\
\hline BS & -0.017244 & 0.010096 & -1.708038 & 0.0882 \\
\hline ACI & 0.000518 & 0.002236 & 0.231656 & 0.8169 \\
\hline F Size & -0.007805 & 0.003290 & -2.371963 & 0.0181 \\
\hline ROE & -0.007397 & 0.005653 & -1.308590 & 0.1913 \\
\hline D1 & -0.020748 & 0.043397 & -0.478102 & 0.6328 \\
\hline $\mathrm{D} 2$ & -0.114318 & 0.109088 & -1.047943 & 0.2952 \\
\hline D3 & 0.107284 & 0.081545 & 1.315631 & 0.1889 \\
\hline D4 & -0.173484 & 0.062499 & -2.775778 & 0.0057 \\
\hline D5 & -0.074463 & 0.147474 & -0.504926 & 0.6138 \\
\hline D6 & 0.012635 & 0.113274 & 0.111542 & 0.9112 \\
\hline D7 & 0.283723 & 0.101211 & 2.803281 & 0.0052 \\
\hline D8 & 0.298333 & 0.092695 & 3.218418 & 0.0014 \\
\hline D9 & 0.140985 & 0.148926 & 0.946675 & 0.3442 \\
\hline D10 & 0.288391 & 0.105930 & 2.722471 & 0.0067 \\
\hline D11 & 0.266340 & 0.168438 & 1.581237 & 0.1144 \\
\hline D12 & 0.152136 & 0.061448 & 2.475861 & 0.0136 \\
\hline D13 & -0.022539 & 0.108327 & -0.208066 & 0.8353 \\
\hline D14 & 0.133342 & 0.232044 & 0.574640 & 0.5658 \\
\hline D15 & -0.034090 & 0.044701 & -0.762622 & 0.4460 \\
\hline D16 & -0.121179 & 0.044390 & -2.729852 & 0.0066 \\
\hline D17 & -0.211534 & 0.044434 & -4.760681 & 0.0000 \\
\hline D18 & -0.287148 & 0.044799 & -6.409670 & 0.0000 \\
\hline $\mathrm{C}$ & 0.671531 & 0.102991 & 6.520305 & 0.0000 \\
\hline R-squared & 0.191649 & Mean dep & ndent var & 0.289258 \\
\hline Adjusted R-squared & 0.152408 & S.D. dep & ndent var & 0.353618 \\
\hline S.E. of regression & 0.325557 & Akaike in & criterion & 0.640310 \\
\hline Sum squared resid & 54.58360 & Schwarz & criterion & 0.846648 \\
\hline Log likelihood & -147.2037 & F-st & istic & 4.883971 \\
\hline Durbin-Watson stat & 1.715653 & $\operatorname{Prob}(\mathrm{F}$ & tatistic) & 0.000000 \\
\hline
\end{tabular}


When variations in time are incorporated with variations in intercepts, all the results remain the same, e.g., BS is still slightly statistically significant with a negative effect on cost of equity while the other governance variables have insignificant results. Only the R-squared and adjusted R-squared terms show any improvement. The entire coefficient taken from time varying coefficients is significantly different, which means that the results obtained for the remaining years are different from those of the excluded dummy year.

\subsection{Corporate Governance Impact on Cost of Equity using CGS}

We have analyzed the impact of individual factors of corporate governance on the cost of equity. Next, we analyze the impact of corporate governance using the CGS approach. First, we perform a descriptive analysis, the results of which are shown in the following table:

Table-7: Descriptive Statistics

\begin{tabular}{lcccc}
\hline & Ke & Log T. Assets & ROE & CGS \\
\hline Mean & 0.291555 & 18.5705 & 0.357792 & 5.625714 \\
Median & 0.186058 & 20.47534 & 0.115425 & 5.6 \\
Minimum & -0.9253 & 3.589059 & -26.8788 & 2.6 \\
Maximum & 1.906467 & 25.14992 & 39.30193 & 8.2 \\
Standard Error & 0.015071 & 0.219629 & 0.105024 & 0.044234 \\
\hline
\end{tabular}

Then we performed a correlation analysis to investigate the relationship between companies with good or bad corporate governance and the cost of their equity. Results indicate that companies with better corporate governance scores have a higher cost of equity. 
Table-8: Correlation Matrix

\begin{tabular}{|c|c|c|c|c|}
\hline & $\mathbf{K e}$ & Log T. Assets & ROE & CGS \\
\hline $\mathrm{Ke}$ & 1 & & & \\
\hline Log T. Assets & $-0.10912^{* *}$ & 1 & & \\
\hline$P$ values & $\underline{0.011182}$ & & & \\
\hline ROE & -0.03533 & 0.044226 & 1 & \\
\hline$P$ values & $\underline{0.416536}$ & $\underline{0.304802}$ & & \\
\hline CGS & 0.032058 & $0.191927^{* * * *}$ & -0.02377 & 1 \\
\hline$P$ values & $\underline{0.457621}$ & $\underline{0.000007}$ & $\underline{0.59348}$ & \\
\hline
\end{tabular}

Values marked with ${ }^{* * *}$ are significant at 0.01 and marked with ${ }^{* *}$ are at 0.02 .

The fixed effect model is represented by the following equation:

$$
Y_{i t}=\alpha_{1 i}+\sum \beta_{1} X_{i t}+\mu_{i t}
$$

The subscript $i$ on the intercept means that the intercepts of the 15 industries sampled may be different, due to industry-specific features.

The above equation can also be written as

$\mathrm{Ke}_{\mathrm{it}}=\propto_{1}+\alpha_{2} \cdot \mathrm{D}_{1 \mathrm{it}} \alpha_{3} \cdot \mathrm{D}_{3 \mathrm{i}}+\ldots \ldots+\alpha_{14} \cdot \mathrm{D}_{14 \mathrm{i}}+\beta_{1} \cdot$ Fsize $+\beta_{2} \cdot \mathrm{CGS}_{\mathrm{it}}+\beta 3 \cdot \mathrm{ROE}_{\mathrm{it}}+\mu_{\mathrm{it}}$

Where $D_{1 \mathrm{i}}$ through $\mathrm{D}_{14 \mathrm{i}}$ are dummy variables which have been used to capture inter-industry intercept differences. Applying the test yields the following results: 
Table-9: Fixed Effect Model (assuming intercept varies across individuals but constant over time)

Dependent Variable: Ke

Included observations: 557 after adjustments

\begin{tabular}{|c|c|c|c|c|}
\hline Variable & Coefficient & Std. Error & t-Statistic & Prob. \\
\hline CGS & 0.001754 & 0.016120 & 0.108786 & 0.9134 \\
\hline F Size & -0.010334 & 0.003263 & -3.166696 & 0.0016 \\
\hline ROE & -0.004150 & 0.005931 & -0.699722 & 0.4844 \\
\hline D1 & -0.022417 & 0.045168 & -0.496309 & 0.6199 \\
\hline D2 & -0.132825 & 0.115499 & -1.150005 & 0.2507 \\
\hline D3 & 0.092572 & 0.082512 & 1.121920 & 0.2624 \\
\hline D4 & -0.186462 & 0.064312 & -2.899325 & 0.0039 \\
\hline D5 & -0.062453 & 0.155865 & -0.400688 & 0.6888 \\
\hline D6 & -0.059119 & 0.112334 & -0.526282 & 0.5989 \\
\hline D7 & 0.196598 & 0.096884 & 2.029207 & 0.0429 \\
\hline D8 & 0.246850 & 0.092446 & 2.670217 & 0.0078 \\
\hline D9 & 0.101780 & 0.156699 & 0.649524 & 0.5163 \\
\hline D10 & 0.297796 & 0.111990 & 2.659120 & 0.0081 \\
\hline D11 & 0.154763 & 0.157639 & 0.981751 & 0.3267 \\
\hline D12 & 0.188253 & 0.062387 & 3.017503 & 0.0027 \\
\hline D13 & 0.116288 & 0.064901 & 1.791767 & 0.0737 \\
\hline D14 & 0.283003 & 0.158130 & 1.789681 & 0.0741 \\
\hline $\mathrm{C}$ & 0.449023 & 0.099138 & 4.529288 & 0.0000 \\
\hline R-squared & 0.095270 & \multicolumn{2}{|c|}{ Mean dependent var } & 0.291687 \\
\hline Adjusted R-squared & 0.066735 & \multicolumn{2}{|c|}{ S.D. dependent var } & 0.356311 \\
\hline S.E. of regression & 0.344217 & \multicolumn{2}{|c|}{ Akaike info criterion } & 0.736692 \\
\hline Sum squared resid & 63.86353 & \multicolumn{2}{|c|}{ Schwarz criterion } & 0.876380 \\
\hline Log likelihood & -187.1688 & \multicolumn{2}{|l|}{ F-statistic } & 3.338708 \\
\hline Durbin-Watson stat & 1.700904 & \multicolumn{2}{|c|}{ Prob(F-statistic) } & 0.000008 \\
\hline
\end{tabular}


By applying the analysis using the CGS, we observed that corporate governance has a positive impact on cost of equity but that this relationship is not significant. While both returns on equity and size of firm have a negative relationship with the cost of equity, only firm size has shown a significant relationship. Most dummies' coefficients have been found significant with very low $\mathrm{p}$ values. This indicates that most of the industries in our analysis have dissimilar coefficients.

Just as individual factors have been analyzed using time and intercept variances, the CGS has also been analyzed using the following equation to capture the time variance effect.

$$
\begin{aligned}
& \mathrm{Ke}_{\mathrm{it}}=\propto_{1}+\alpha 1 \cdot \mathrm{D}_{1 \mathrm{it}} \alpha_{3} \cdot \mathrm{D}_{3 \mathrm{i}}+\ldots \ldots . .+\alpha_{14} \cdot \mathrm{D}_{14 \mathrm{i}}+\Upsilon_{0}+\Upsilon_{1} \cdot \mathrm{D}_{15}+\Upsilon_{2} \cdot \mathrm{D}_{16}+\Upsilon_{3} \cdot \mathrm{D}_{17}+ \\
& \Upsilon_{4} \cdot \mathrm{D}_{18}+\beta_{1} \cdot \mathrm{CGS}_{\mathrm{it}}+\beta 2 \cdot \mathrm{Fize}_{\mathrm{it}}+\beta 3 \cdot \mathrm{ROE}_{\mathrm{it}}+\mu_{\mathrm{it}}
\end{aligned}
$$

Where $\mathrm{D}_{15}+\mathrm{D}_{16}+\mathrm{D}_{17}+\mathrm{D}_{18}$ are time dummies used to capture the difference of intercept due to time. 
Table-10: Fixed Effects Model, (assuming intercept varies across individuals as well as over time)

\begin{tabular}{|c|c|c|c|c|}
\hline $\begin{array}{l}\text { Dependent Variabl } \\
\text { Method: Least Squ } \\
\text { Date: 07/09/08 Ti } \\
\text { Sample (adjusted): } \\
\text { Included observati }\end{array}$ & $\begin{array}{l}\text { Ke } \\
\text { res } \\
\text { le: } 15: 19 \\
560 \\
\text { ns: } 558 \text { after }\end{array}$ & adjustments & & \\
\hline Variable & Coefficient & Std. Error & t-Statistic & Prob. \\
\hline$\overline{\text { CGS }}$ & 0.002789 & 0.015236 & 0.183075 & 0.8548 \\
\hline F Size & -0.009429 & 0.003111 & -3.030566 & 0.0026 \\
\hline $\mathrm{ROE}$ & -0.007737 & 0.005680 & -1.362077 & 0.1737 \\
\hline D1 & -0.029397 & 0.042812 & -0.686658 & 0.4926 \\
\hline D2 & -0.125856 & 0.110009 & -1.144047 & 0.2531 \\
\hline D3 & 0.085427 & 0.078612 & 1.086692 & 0.2777 \\
\hline D4 & -0.188081 & 0.061263 & -3.070074 & 0.0022 \\
\hline D5 & -0.067580 & 0.148487 & -0.455128 & 0.6492 \\
\hline D6 & -0.059342 & 0.106998 & -0.554610 & 0.5794 \\
\hline D7 & 0.193883 & 0.092219 & 2.102432 & 0.0360 \\
\hline D8 & 0.244515 & 0.088054 & 2.776876 & 0.0057 \\
\hline D9 & 0.100797 & 0.149267 & 0.675280 & 0.4998 \\
\hline D10 & 0.294447 & 0.106685 & 2.759961 & 0.0060 \\
\hline D11 & 0.146973 & 0.150178 & 0.978662 & 0.3282 \\
\hline D12 & 0.183917 & 0.059437 & 3.094301 & 0.0021 \\
\hline D13 & 0.108948 & 0.061823 & 1.762253 & 0.0786 \\
\hline D14 & 0.273392 & 0.150636 & 1.814923 & 0.0701 \\
\hline D15 & -0.028453 & 0.044026 & -0.646281 & 0.5184 \\
\hline D16 & -0.111762 & 0.043993 & -2.540413 & 0.0114 \\
\hline D17 & -0.197570 & 0.044045 & -4.485659 & 0.0000 \\
\hline D18 & -0.286350 & 0.044274 & -6.467691 & 0.0000 \\
\hline $\mathrm{C}$ & 0.554796 & 0.097005 & 5.719275 & 0.0000 \\
\hline R-squared & 0.183519 & Mean deper & dent var & 0.291560 \\
\hline Adjusted R-squared & 0.151530 & S.D. depen & ent var & 0.356004 \\
\hline S.E. of regression & 0.327924 & Akaike info & criterion & 0.646558 \\
\hline Sum squared resid & 57.63830 & Schwarz cri & erion & 0.817053 \\
\hline Log likelihood & -158.3898 & F-statistic & & 5.736939 \\
\hline Durbin-Watson stat & 1.687970 & Prob(F-stati & tic) & 0.000000 \\
\hline
\end{tabular}

The results are the same as has been discussed while keeping time constant and varying the intercept over individual variables. The coefficients of time are significantly different from each other. The R-squared and 
adjusted R-squared terms have also been improved by taking the time effect into consideration.

\section{Discussion of Results}

Our study leads us to the following conclusions:

a. Board size is negatively related to the cost of equity, i.e., a larger board brings down the cost of equity. This can be explained by the argument that when the board size is large, no single stakeholder can dominate its decision-making process. Its first impact is on the reduction of agency costs. Better decisions taken by a nonpartisan board for the overall good of all stakeholders also improve the image of the company. In turn, these factors lower the company's risk profile and curtail the cost of its equity.

b. Managerial ownership has a negative impact on a company's cost of equity, i.e., a higher number of shares (as a percentage of the company's total issued shares) held by board members leads to a higher cost of equity. Conversely, if the percentage of shareholding commanded by board members is low, the cost of company's equity is low. This can be explained by the fact that if a board is not dominated by one group of shareholders, it is likely to have a more balanced and representative structure. A balanced board reduces the possibilities of lopsided decision making, preventing any particular class of stakeholders from furthering its interest at the expense of other stakeholders. In turn, it leads to better image, lower risk profile, and lower cost of equity.

c. Surprisingly, board independence and audit committee independence were found to have a positive although insignificant effect on a company's cost of equity. One would generally expect board independence and the presence of an independent audit committee to lower a company's risk profile and hence the cost of its equity. Yet, in our sample, our findings were not consistent with this generally held view. However, there is a plausible explanation for this distortion. In Pakistan, neither the law nor practice draws any distinction between independent nonexecutive directors (INEDs) and nonexecutive directors (NEDs). Pakistani companies thus invariably classify their NEDs as INEDs. This explains why investors may be oblivious of the so-called independence of the board (as indicated by number of NEDs on the board). This theory is also sustained by the rather insignificant relationship between board/audit committee 
independence and cost of equity. The other reason here could be that our data are dominated by the spinning sector. Most firms in this sector are seth $\left({ }^{* *}\right)$ owned, the presence of whom is likely to limit the independence of NEDs. We believe a more detailed investigation is needed in this area, for which one would need to determine the true level of independence of boards (and audit committees) with access to accurate statistics on the number of truly independent directors on each board. This task cannot be accomplished by analyzing only published financial statements.

d. Firm size and return on equity have been found to be negatively related to the cost of equity. This is hardly surprising as larger and more profitable firms are deemed to carry lower risk and therefore enjoy greater public confidence, leading to lower demand for returns by investors.

e. An important albeit conflicting observation emerges from our study. When these variables were analyzed collectively to reveal their impact on cost of equity using the CGS, it was found to be positively but insignificantly correlated with cost of equity. This would imply that the CGS has no impact on cost of equity. The CGS takes into account a number of aspects of corporate governance performance, with each individual aspect having its own distinct impact on the cost of equity. We believe that the overall insignificant impact of the CGS on COE is caused by the positive impact of certain individual aspects of CG being offset by the negative impact of other factors. Another reason for this apparently conflicting result could be the selection of our sample, which includes a large number of firms from the textile sector. Most firms in this sector are family-owned businesses, who, in this part of the world, are not known to have any real regard for good corporate governance. The investing public is therefore generally oblivious to the CGS of such firms, explaining partially the insignificance of the relationship between CGS and cost of equity.

\section{Conclusion and Recommendations}

In this study, comprehensive data have been used to investigate and analyze the relationship between corporate governance and cost of equity. Good corporate governance is rightfully seen as the most important task of today's regulators, planners, industry leaders, and managers. On the other hand, the cost of equity is the axis on which revolves the prospects of a 
company's growth and expansion. Formally exploring the relationship between these important aspects of the economy has been opportune and timely.

We conclude that good corporate governance reduces a company's cost of equity. This in turn facilitates decision-makers in considering new investments in feasible projects. Investors show greater faith in companies that have a consistent profitability profile and a large assets base.

As mentioned earlier, one important aspect of corporate governance that has been highlighted by this study is the fact that boards and audit committees are not as independent in Pakistan as the development of a good corporate governance culture would demand. One reason for this could be that the data are skewed toward the spinning sector, in which most companies are family-owned. Another reason for this state of affairs is the absence of a clear definition of INEDs in Pakistan. Companies are inclined to label all NEDs as independent at will. We believe there is an immediate need for the law to come up with a precise and enforceable definition of INEDs, and for regulators to ensure that it is properly followed. With the emergence of truly independent directors, who act not for a particular stakeholder but for the collective interest of all stakeholders, companies will become more transparent in their decision making. In turn, this should lead to better corporate governance and greater investor confidence in listed companies.

Based on the findings of this study, we recommend the following:

1. This study, as well as the literature reviewed for the purpose of the study, shows that there is an urgent need to introduce and effectively enforce laws for better corporate governance in Pakistan. Better corporate governance will bring down the cost of equity, leading to greater investment in new projects, bringing about greater overall development for the economy. The Code of Corporate Governance 2002 should be revised to encompass more stringent measures and be made mandatory for all listed companies.

2. Our study was limited in one particular respect: the aspects of good corporate governance included in the CGS. These were limited principally due to nonavailability of data from published sources on all aspects of corporate governance. We believe that, by considering a greater volume of data and including more variables in the CGS, more reliable results can be obtained. The study leaves room for further research on the topic by including more variables in the CGS and calculating Ke using other available models. 


\section{References}

Andrea M., 2004, "Financial Reporting, Corporate Communication and Governance," Corporate Ownership \& Control 1.

Ashbaugh, Collins, Lafond, 2004, "Corporate Governance and the Cost of Equity Capital,” Working Paper.

Beasley, M., 1996, "An Empirical Analysis of the Relation between the Board of Director Composition and Financial Statement Fraud," The Accounting Review, Vol. 71, No. 4 : 443-465.

Bebchuck, Cohen, Fere11, 2009, "What Matters in Corporate Governance," Review of Financial Studies, Vo1. 22 : 783-827

Beidleman, C.R., 1973, "Income Smoothing, The Role of Management," The Accounting Review, Vol. 48 : 653-667

Billet, M. Flannery, J. Garfinke1, 1995, "The Effect of Lender Identity on Borrowing Firm's Equity Returns," Journal of Finance, Vo1. 50 : 669-718.

Black and Scholes, 1973, "The Pricing of Options and Corporate Liabilities," Journal of Political Economy, Vo1. 81 : 637-654.

Black, Bernard, Hasung Jang and Woochan Kim, 2003, "Does Corporate Governance Affect Firm Value? Evidence from Korea," Working Paper, Stanford Law School.

Burkhart, Mike, Denis Gromb, and Fausto Panunzi, 1997, "Large Shareholders, Monitoring, and the Value of the Firm," Quarterly Journal of Economics, Vo1. 112 : 693-728.

Chen, Kevin C.W., and Hongqi Yuan, 2004, "Earnings Management and Capital Resource Allocation: Evidence from China's AccountingBased Regulation of Rights Issues,”Accounting Review, Vol. 79 : 645-665

Claus, J. and J. Thomas, 2001, "Equity Premia as Low as Three Percent? Evidence from Analysts Earnings Forecasts for Domestic and International Stock Markets,” Journal of Finance, Vol. 56 : 16291666. 
Cohen, Jeffrey, Krishnamoorthy, Ganesh, Wright, Arnie, 2004, "Corporate Governance Mosaic and Financial Reporting Quality," Journal of Accounting Literature.

Core, John and Larcker, D., 2002, "Performance Consequences of Mandatory Increases in Executive Stock Ownership," Journal of Financial Economics, Vo1. 64 : 317-340.

David Hess, "Social Reporting and New Governance Regulation: The Prospects of Achieving Corporate Accountability through Transparency,” Ross School of Business, University of Michigan.

Dechow, P., R. Sloan and A. Sweeney, 1996, "Causes and Consequences of Earnings Manipulation: An Analysis of Firms Subject to Enforcement Action by the SEC," Contemporary Accounting Research, Vol. 13 : $1-36$.

Dechow, P.M., R.G. Sloan, A.P. Sweeney, 1995, "Detecting Earning Management," The Accounting Review, Vol. 70 : 115-139.

Denis, Diane and John McConnell, 2005, "International Corporate Governance," Journal of Financial and Quantitative Analysis, Forthcoming.

Douglas, George W., 1969, "Risk in the Equity Markets: An Empirical Appraisal of Market Efficiency," Yale Economic Essays, Vo1. 9 : 3-45

Easton, P., 2004, "PE Ratios, PEG Ratios, and Estimating the Implied Expected Rate of Return on Equity Capital," The Accounting Review, Vo1. 79 : 73-95.

Fama, E. and MacBeth, J., 1973, "Risk, Return and Equilibrium: Empirical Tests,” Journal of Political Economy, Vo1. 81 : 607-636.

Gebhardt, W., C. Lee, and B. Swaminathan, 2001, "Towards an Implied Cost of Capital," Journal of Accounting Research, Vol. 39 : 135-176.

Grinstein, Yaniv, and Vidhi Chhaochharia, 2005, "Corporate Governance and Firm Value - The Impact of the 2002 Governance Rules," The Journal of Finance.

Guay W. and S.P. Kothari, 2003, "How Much Do Firms Hedge With Derivatives?” Journal of Financial Economics, Vol. 70 : 423-461. 
Guedhami \& Mishra, 2006, "Excess Contro1, Corporate Governance, and Implied Cost of Equity: An International Evidence,” Working Paper.

Hermalin, Benjamin, and Michael Weisbach, 1998, "Endogenously Chosen Boards of Directors and their Monitoring of the CEO," American Economic Review, Vol. 88 : 96-118.

Himmelberg C, Hubbad R, Palia D., 1999, "Understanding the Determinants of Ownership and link between Ownership and Performance," Journal of Financial Economics, Vo1. 53 : 353-384.

Hope, Kang Thomas and Yoo, 2007, "Impact of Excess Auditor Remuneration on Cost of Equity Capital around the World." Working Paper.

Jensen Michael and William Meckling, 1976, "Theory of the Firm: Managerial Behavior, Agency Costs and Capital Structure," Journal of Financial Economics, Vo1. 3 : 305-360.

Kessler, Danie1, and Steven Levitt, 1999, "Using Sentence Enhancements to Distinguish between Deterrence and Incapacitation," Journal of Law and Economics, Vo1. 17 (1) : 343-363.

Klapper, Leora F. \& Inessa Love, 2002, "Corporate Governance, Investor Protection and Performance in Emerging Markets," World Bank Working Paper.

Klein, A., 2002, "Audit Committee, Board of Director Characteristics, And Earning Management," Journal of Accounting and Economics, Vol. $33: 375-400$.

Krugman, Pau1, 2002, "Fear of All Sums." New York Times, June 21 w.pkarchive.org/column/062102.htm1

La Porta, R1, F Lopez-de-Silances, A Shleifer, and R W. Vishny, 1998, "Law and Finance," Journal of Political Economy, Vol. 106 (6) : 11131155 .

Lambert and Larcker, 2004, "Stock Options, Restricted Stock, and Incentives,” Working Paper, University of Pennsylvania.

Lambert R.A., 1984, "Income Smoothing As Rational Behavior," The Accounting Review, Vol. 59 : 604-618. 
Levitt, A., 1998, "The Numbers Game" Remarks Delivered at the NYU Center for Law and Business," New York.

Lintner, John, 1965, "The Valuation of Risky Assets and the Selection of Risky Investment in Stock Portfolios and Capital Budgets.” Review of Economics and Statistics, Vol. $47: 13-37$.

Lipe, R., 1990, "The Relation between Stock Returns and Accounting Earnings Given Alternative Information," The Accounting Review, Vo1. $65: 49-71$.

Markowitz, H., 1952, "Portfolio Selection,” Journal of Finance, Vo1. 7 : 7791.

Menon, K and D. Williams, 2004, "Former Audit Partners and Abnormal Accruals," The Accounting Review, Vol. 79 : 1095-1118.

Miller, Merton H., and Myron Scholes, 1972, "Rate of Return in Relation to Risk: A Re-Examination of Some Recent Findings," in Michael C. Jensen, ed, Studies in the Theory of Capital Markets : 47-78.

Nohe1, T. and V Tahran, 1998, "Share Repurchases and Firm Performance: New Evidence on Agency Cost of Free Cash Flow," Journal of Financial Economics, Vo1. 49 : 187-222.

Ohlson, J., and B. Juettner-Nauroth, 2000, "Expected EPS and EPS Growth as Determinants of Value," Working Paper, New York University.

Palmrose, Z-V., V. J. Richardson, and S. Scholz, 2003, "Determinants of Market Reactions to Restatement Announcements," Journal of Accounting and Economics.

Pincus, M. and S. Rajgopal, 2002, "The Interaction of Accrual Management and Hedging: Evidence from Oil and Gas Firms," The Accounting Review, Vo1. 71 : 27-160.

Pincus, M.A and S.R. Thiagarajan, 2000, "Risk Measurement and Hedging: With and Without Derivatives," Financial Management, Vo1. 29 : 5 30 .

Rafael La Porta, Florencio Lopez de Silanes, Andrei Schleifer, and Robert W. Vishny, 1999, “Corporate Ownership Around the World,” Journal of Finance, Vo1. 54 : 471-517. 
Richardson, S., I. Tuna and M. Wu, 2002,"Predicting Earnings Management: The Case of Earnings Restatements," Working Paper, University of Pennsylvania.

Schipper, K and L Vincent, 2003, "Earning Quality," Accounting Horizons, Vol. $17: 97-110$.

Sharpe, William, 1964, "Capital Asset Prices: A Theory of Market Equilibrium under Conditions of Risk,” Journal of Finance, Vo1. 19 : 425-442.

Smith, C. and R Stulz, 1985, "The Determinants of Hedging Policies," Journal Of Financial And Quantitative Analysis, Vol. 20 : 391-405.

Smith, Michael, 1996, "Shareholder Activism by Institutional Investors: Evidence from CALPERS,” Journal of Finance, Vo1. 52 : 227-252.

Tobin, James, 1958, "Liquidity Preference as a Behaviour Toward Risk," Review of Economic Studies, Vo1. 25 : 65-86.

Visvanathan, G., 1998, "Who Uses Interest Rate Swaps? A Cross-Sectional Analysis," Journal of Accounting, Auditing and Finance, Vol. 13 : 173-200.

Wei-Peng Chen, Huimin Chung, Cheng_F. Lee, and Wei-Li Liao, 2007, "Corporate Governance and Equity Liquidity," An Analysis of S\&P Transparency and Disclosure Ranking, Corporate Governance: An International Review, Vo1. 15 (4) : 644-660.

Yermack, David, 1996, "Higher Market Valuation of Companies with a Small Board of Directors," Journal of Financial Economics, Vo1. 40 : 185-211. 
Appendix-A

Company Name

\begin{tabular}{|c|c|c|c|}
\hline \multicolumn{4}{|c|}{ Period covered } \\
\hline Symbol & Variable & Definition & 2006 \\
\hline OWNCON $\mathfrak{j}, \mathrm{t}$ & $\begin{array}{c}\text { Ownership } \\
\text { Concentration }\end{array}$ & $\begin{array}{l}\text { Percentage of total shares held by } \\
\text { the top } 20 \text { shareholders divided } \\
\text { by the total number of shares. }\end{array}$ & \\
\hline OWNMANj,t & $\begin{array}{l}\text { Managerial } \\
\text { Ownership }\end{array}$ & $\begin{array}{l}\text { Percentage of total shares held by } \\
\text { executive directors divided by the } \\
\text { total number of shares. }\end{array}$ & \\
\hline BRDINDjt & $\begin{array}{l}\text { Board } \\
\text { Independence }\end{array}$ & $\begin{array}{l}\text { independent directors divided by } \\
\text { the total number of Directors }\end{array}$ & \\
\hline BRDSZEjt & Board Size & Number of directors on the board. & \\
\hline AUDINDjt & $\begin{array}{c}\text { Audit } \\
\text { Committee } \\
\text { Independence }\end{array}$ & $\begin{array}{l}\text { Number of independent directors } \\
\text { on the audit committee divided by } \\
\text { the total number of directors on } \\
\text { the audit committee. }\end{array}$ & \\
\hline
\end{tabular}




\section{Appendix-B}

Scoring Criteria and their weights

Presence of INED's in the Board \& In Audit Committee: Weight 55\%

\section{Board Structure:}

Directors are governor of companies. Therefore board structure is core issue of corporate governance. A balanced and effective board is considered essential for good governance.

1. Number of INEDs:

$\begin{array}{cc}\text { Range } & \text { Score } \\ 0 \%------20 \% & 1 \\ 21 \%------40 \% & 2 \\ 41 \%-------60 \% & 3 \\ 61 \%---80 \% & 4 \\ 81 \% \text { and above } & 5\end{array}$

2. No. Of INEDs in Audit Committee:

$\begin{array}{cc}\text { Range } & \text { Score } \\ 0 \%------20 \% & 1 \\ 21 \%------40 \% & 2 \\ 41 \%------60 \% & 3 \\ 61 \%----80 \% & 4 \\ 81 \% \text { and above } & 5\end{array}$

Ownership structure (Weight 45\%)

1. Ownership Concentration

$\begin{array}{cc}\text { Range } & \text { Score } \\ 0 \%-------20 \% & 5 \\ 21 \%-------40 \% & 4 \\ 41 \%--------80 \% & 3 \\ \text { 61\%-----80\% } & 2 \\ 81 \% \text { and above } & 1\end{array}$

2. \%age of shares held by Board of Directors

$\begin{array}{cc}\text { Range } & \text { Score } \\ 0 \%------20 \% & 5 \\ 21 \%------40 \% & 4 \\ 41 \%-------60 \% & 3 \\ 61 \%-----80 \% & 2 \\ 81 \% \text { and above } & 1\end{array}$




\section{Appendix- $C$}

\section{Ohlson and Jeuttner Nauroth (2005)}

$$
K=A+\sqrt{A^{2}+\frac{e_{1}}{P_{0}}\left[g_{2}-(y-1)\right]}
$$

Where

$$
\begin{aligned}
& \mathrm{K}=\text { cost of equity } \\
& \mathrm{A}=\left[(\mathrm{y}-1)+\mathrm{D} 1 / \mathrm{P}_{\mathrm{o}}\right] \\
& \mathrm{e}_{1}=\text { Earnings per share for year } 1 \\
& \mathrm{~g}_{2}=\mathrm{e}_{2-} \mathrm{e}_{1 /} \mathrm{e}_{1} \\
& \mathrm{e}_{2}=\text { Earnings per share for year } 2 \\
& \mathrm{Y}=\text { constant }(1+\text { growth rate } \mathrm{g}) \\
& \mathrm{D} 1=\mathrm{e}_{1} * \text { dividend payout ratio. }
\end{aligned}
$$

\section{Claus and Thomas (2001)}

$P_{T}=B_{T}+\frac{E_{T+1}-\mathrm{KB}_{\mathrm{T}}}{(1+\mathrm{K})}+\frac{\mathrm{EPS}_{\mathrm{T}+2}-\mathrm{KB}_{\mathrm{T}+1}}{(1+\mathrm{K})^{2}}+. .+\frac{\mathrm{EPS}_{\mathrm{T}+5}-\mathrm{KB}_{\mathrm{T}+4}}{(1+\mathrm{K})^{5}}+\frac{\left(\mathrm{EPS}_{\mathrm{T}+5}-\mathrm{KB}_{\mathrm{T}+4}\right)(1+\mathrm{gn})}{(\mathrm{K}-\mathrm{gn})(1+\mathrm{K})^{5}}$

Where

$$
\begin{aligned}
& \mathrm{P}_{\mathrm{T}}=\text { Price per share } \\
& \mathrm{B}_{\mathrm{T}}=\text { Current Book Value } \\
& \text { EPS }{ }_{\mathrm{T}^{*} \mathrm{~J}}=\text { Forecast of future earnings per share } \\
& \mathrm{g}_{\mathrm{n}}=\text { long term growth rate } \\
& \mathrm{K}=\text { cost of equity capital } \\
& \mathrm{B}_{\mathrm{T}+\mathrm{I}}=\mathrm{B}_{\mathrm{T}+\mathrm{i}-1}+\mathrm{EPS}_{\mathrm{T}+\mathrm{i}}-\mathrm{P}_{\mathrm{T}+\mathrm{i}}
\end{aligned}
$$

\section{Easton (2004)}

$$
P_{T}=\frac{E P S_{T+2}+K D_{T+1}-E P S_{T+1}}{\mathrm{M}^{2}}
$$

Where

$$
\mathrm{D}_{\mathrm{T}+\mathrm{i}}=\mathrm{EPS}_{\mathrm{T}+\mathrm{i}} * \text { Dividend payout ratio }
$$

